\title{
Rubratoxin B induces apoptosis in HL-60 cells in the presence of internucleosomal fragmentation
}

\author{
Hitoshi Nagashima* and Tetsuhisa Goto*
}

(Received Sept. 16, 1997 ; Accepted Dec. 19, 1997)

\author{
長嶋＼cjkstart等*，後藤 哲久*：ルブラトキシン B は HL-60 細胞にヌクレオソーム間の \\ 切断を伴ったアポトシースを誘導する
}

\begin{abstract}
Summary
To test the hypothesis that the toxicity of rubratoxin $\mathrm{B}$ is a consequence of apoptosis, we investigated fragmentation of nuclei and internucleosomal fragmentation (DNA ladder). Exposure to rubratoxin B caused HL-60 cells to condense their chromatins and fragment their nuclei, showing that rubratoxin $B$ induces apoptosis. We observed DNA ladder in HL-60 cells treated with rubratoxin B for $24 \mathrm{hr}$. Cycloheximide did not affect rubratoxin B-induced DNA ladder. Therefore, rubratoxin B-induced apoptosis is considered not to require protein synthesis. Twenty four-hr treatment of rubratoxin B or ethylene glycol-bis ( $\beta$-aminoethyl ether) -tetraacetic acid (EGTA) alone resulted in DNA ladder, but no DNA ladder treated with both chemicals for $24 \mathrm{hr}$. Eight-hr treatment of rubratoxin B and EGTA resulted in DNA ladder, suggesting that long exposure to both chemicals led to post-apoptotic DNA degradation. Since the addition of $\mathrm{Ca}^{2+}$ inhibited the effect of EGTA, the reduction of extracellular $\mathrm{Ca}^{2+}$ concentration by EGTA appears to cause an enhancement of rubratoxin B-induced DNA degradation.
\end{abstract}

Key words : Rubratoxin B, ルブラトキシン B; Apoptosis, アポトーシス; DNA ladder, DNA ラダー; EGTA, EGTA

\section{Introduction}

Rubratoxin $\mathrm{B}$ is a potent hepatotoxic ${ }^{1,2)}$ and teratogenic ${ }^{3,4)}$ mycotoxin produced by the fungi Penicillium rubrum and Penicillium purpurogenum ${ }^{2,5}$. Biochemical and cytological changes such as inhibition of $\mathrm{Na}^{+}, \mathrm{K}^{+}$-ATPase ${ }^{6}$, decrease in levels of hepatic ATP and cyclic AMP), inhibition of hepatic cytochrome P-450-dependent monooxygenase ${ }^{8)}$, reduction of hepatic and renal nonprotein sulfhydryl content ${ }^{9)}$ and inhibition of gap junctional intercellular communication $^{10}$ ) by rubratoxin $\mathrm{B}$ have been reported. Nevertheless, the mechanism of its toxicity remains unclear. Exposure to rubratoxin B resulted in shrinkage of HepG2 and HeLa cells, and a corresponding reduction in cell volume ${ }^{11)}$. Rubratoxin B did not affect the cell cycle of HepG2 and HeLa cells, but brought about a dose-dependent increase of degraded chromosomal DNA $^{11)}$. The reduction of cell volume and the degradation of chromosomal DNA suggest that the toxicity of rubratoxin $\mathrm{B}$ is the consequence of apoptosis. Moreover, caspase inhibitor

\footnotetext{
* National Food Research Institute, Ministry of Agriculture, Forestry and Fisheries, 2-1-2 Kannondai, Tsukuba, Ibaraki 305, Japan

農林水産省食品総合研究所(テ305つくば市観音台 2-1-2)
} 
partially inhibited rubratoxin B-induced morphological change of human umbilical vein endothelial cells, suggesting that caspases are involved in its apoptotic signal transduction ${ }^{10)}$. Other than our observations, the characteristics of apoptosis such as the appearance of polynuclear cells $^{12)}$ and the loss of renal microvilli ${ }^{13)}$ were reported. To test this hypothesis, we investigated fragmentation of nuclei and internucleosomal fragmentation (DNA ladder), which are histological and biochemical characteristics of apoptosis, respectively ${ }^{14}$. Besides, to get clues to the mechanism of apoptosis, we also investigated the effects of the protein synthesis inhibitor cycloheximide $(\mathrm{CHX})$ and $\mathrm{Ca}^{2+}$ chelator ethylene glycol-bis ( $\beta$-aminoethyl ether)-tetraacetic acid (EGTA) on rubratoxin B-treated cells.

\section{Materials and Methods}

Chemicals and Cells Rubratoxin B was purchased from Makor Chemicals (Israel). Cultured human promyelocytic leukemia cell line HL-60 was purchased from RIKEN Cell Bank (Japan). Cells were cultured in RPMI 1640 medium containing 10\% fetal calf serum.

Morphological Study Four times $10^{5}$ cells in $2 \mathrm{ml}$ of medium with $40 \mu \mathrm{g} / \mathrm{ml}$ rubratoxin B were cultured in a glass bottom culture dish $(\phi 3.5 \mathrm{~cm})$ for $24 \mathrm{hr}$, then stained with $5 \mu \mathrm{g} / \mathrm{ml}$ Hoechst 33258 at $37^{\circ} \mathrm{C}$ for $30 \mathrm{~min}^{15}$. The nuclei were examined by fluorescence microscopy.

Examination of DNA fragmentation Four times $10^{5}$ cells treated with chemicals were placed in each well of a 6 -well plate. Cells were collected by centrifugation, and lysed in $1 \mathrm{ml}$ of $50 \mathrm{mM}$ Tris-HCI pH 8.0, $100 \mathrm{mM}$ EDTA, 0.5\% SDS. Samples were treated with $50 \mu \mathrm{g} / \mathrm{ml} \mathrm{RNase} \mathrm{A} \mathrm{at}$ $37^{\circ} \mathrm{C}$ for $30 \mathrm{~min}$ and then treated with $100 \mu \mathrm{g} / \mathrm{ml}$ proteinase $\mathrm{K}$ at $37^{\circ} \mathrm{C}$ for $30 \mathrm{~min}$, followed by 2-propanol precipitation. Pellets were suspended in $45 \mu \mathrm{l}$ of $10 \mathrm{mM}$ Tris-HCI pH $8.0,1 \mathrm{mM}$ EDTA and then $16 \mu$ l of each sample was loaded onto a $2 \%$ agarose gel in $0.5 \times$ TBE buffer (90 $\mathrm{mM}$ Tris-borate, $2 \mathrm{mM}$ EDTA) containing $0.5 \mu \mathrm{g} / \mathrm{ml}$ ethidium bromide.

\section{Results and Discussion}

To test the hypothesis that rubratoxin $\mathrm{B}$ induces apoptosis ${ }^{11)}$, we investigated the morphological change of nuclei induced by rubratoxin $B$, because the condensation of chromatin and nuclear fragmentation are the typical morphological changes of apoptosis ${ }^{14)}$. Compared to the control (Fig. 1A), chromatins in rubratoxin B-treated cells were condensed (Fig. 1B). Furthermore, several dense spheres appeared (Fig. 1B) as a result of nuclear fragmentation. Therefore, these results showed that rubratoxin B induced apoptosis in HL-60 cells.

Since apoptosis nuclear fragmentation is often accompanied by DNA ladder, we investigated the appearance of DNA ladder. DNA ladder is one of the biochemical characteristics of apoptosis, though, in certain cases, necrosis was accompanied by DNA ladder ${ }^{16)}$. As shown in Fig. 2A, we observed DNA ladder in HL-60 cells treated with $80 \mu \mathrm{g} / \mathrm{ml}$ and $40 \mu \mathrm{g} / \mathrm{ml} \mathrm{rubratoxin}$ $\mathrm{B}$ for $24 \mathrm{hr}$ (Fig. $2 \mathrm{~A}$; lanes 3, 4). Thus, rubratoxin B-induced apoptosis in HL-60 cells appears to be accompanied by DNA ladder. Time course analysis showed that DNA ladder appeared with 12 -hr treatment of $40 \mu \mathrm{g} / \mathrm{ml}$ rubratoxin B (Fig. 3A ; lane 4). We also observed DNA ladder in the human hepatoma cell line HepG2 treated with rubratoxin B for $24 \mathrm{hr}$ (data not shown). However, we did not detect DNA ladder in HeLa cells even after a $72 \mathrm{hr}$-treatment of rubratoxin 


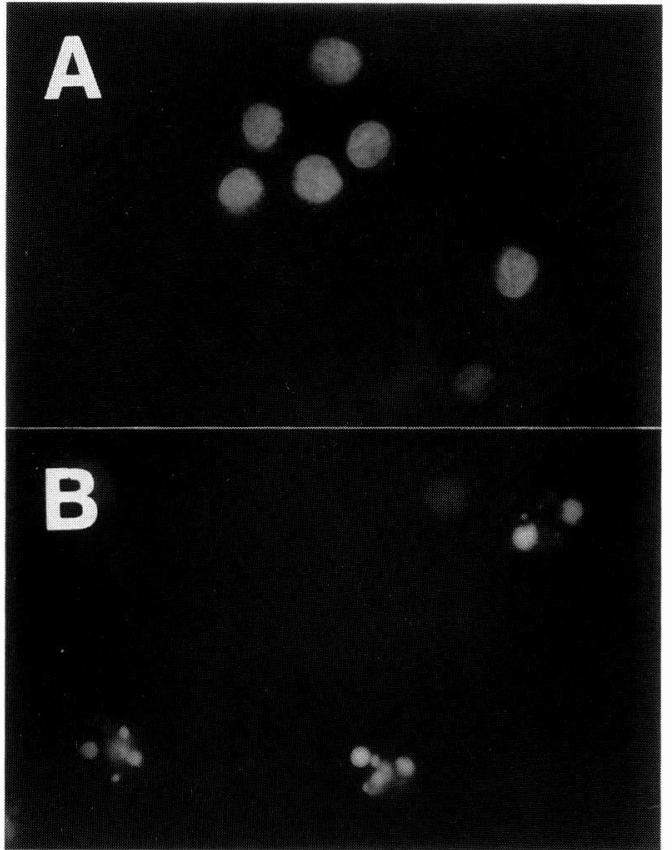

Fig. 1 Morphological change of HL-60 cell nuclei by rubratoxin B. (A) Contorl ; (B) treated with $40 \mu \mathrm{g} /$ $\mathrm{ml}$ rubratoxin $\mathrm{B}$ for $24 \mathrm{hr}$. (Magnification $\times 400$ )
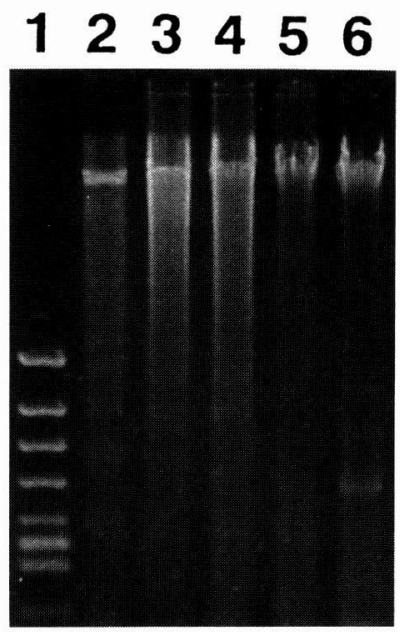

Fig. 2 Agarose gel electrophoresis of DNA from rubratoxin B-treated HL-60 cells. Lanes 3-6 correspond to HL-60 cells treated with $80,40,20$ and $0 \mu \mathrm{g} / \mathrm{ml}$ rubratoxin B for $24 \mathrm{hr}$, respectively. Lane 1 contains molecular weight marker ( $\phi$ X174 Hinc II digest, molecular weights are 1,057 bp, 770 bp, 612 bp, 495 bp, 392 bp, 345 bp, 341 bp, 335 bp, 297 bp, 291 bp and 210 bp.). Lane 2 contains positive control (HL-60 cells treated with $1 \mu \mathrm{g} / \mathrm{ml}$ camptothecin for $4 \mathrm{hr}$ ).

B (data not shown). Ueno et al. reported that rubratoxin B did not induce DNA fragmentation in HL-60 cells ${ }^{17)}$. It is possible that they could not detect DNA ladder because of some 


\section{A}

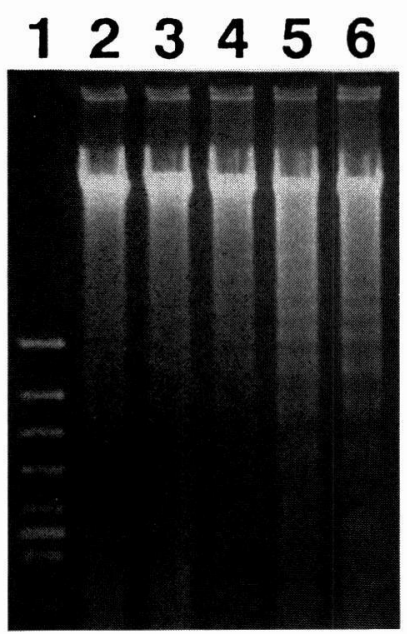

B

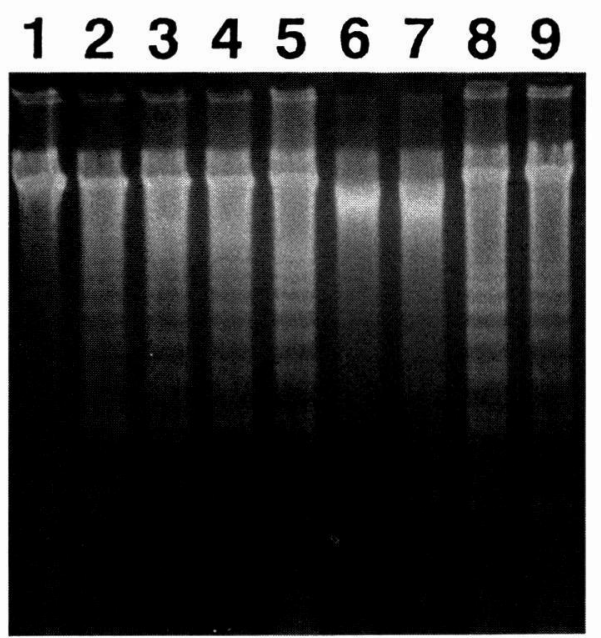

Fig. 3 Time course analysis of (A) and effects of cyoloheximide (CHX) and EGTA on (B) rubratoxin B-induced DNA fragmentation in HL-60 cells. (A) Lanes 2-6 correspond to HL-60 cells treated with $40 \mu \mathrm{g} / \mathrm{ml}$ rubratoxin B for $0,8,12,16$ and $24 \mathrm{hr}$, respectively. Lane 1 contains molecular weight marker ( $\phi$ X174 Hinc II digest). (B) Lanes 2-5 correspond to HL-60 cells treated with 2, $1,0.5$ and $0 \mu \mathrm{g} / \mathrm{ml} \mathrm{CHX}$ in the presence of $40 \mu \mathrm{g} / \mathrm{ml}$ rubratoxin B for $24 \mathrm{hr}$, respectively. Lanes 6-9 correspond to HL-60 cells treated with 2, 1, 0.5 and $0.25 \mathrm{mM}$ EGTA in the presence of $40 \mu \mathrm{g} /$ $\mathrm{ml}$ rubratoxin $\mathrm{B}$ for $24 \mathrm{hr}$, respectively. Lane 1 contains negative control (untreated HL-60 cells).

differences in experimental conditions. Since rubratoxin B induces apoptosis in HL-60 cell line which is descended from a myeloid leukemia cell, our results also suggest the possibility that rubratoxin B is immunotoxic as well as hepatotoxic and teratogenic. Several groups reported that rubratoxin $\mathrm{B}$ was toxic $\mathrm{to}^{2,18,19)}$ or suppressive $\mathrm{on}^{20)}$ the immune system. Our results are consistent with their observations.

To ascertain whether rubratoxin B-induced apoptosis is dependent on protein synthesis, we investigated the effect of the protein synthesis inhibitor CHX on rubratoxin B-treated HL-60 cells. While CHX induced DNA ladder in HL-60 cells (data not shown), in this experiment, CHX inhibited the proliferation of $\mathrm{HL}-60$ cells, and as a result, the amount of total chromosomal DNA decreased slightly according to the increase of the concentration of CHX (Fig. 3B ; lanes 2-4). However, any concentrations of CHX we used made little effect on rubratoxin B-induced DNA fragmentation in HL-60 cells (Fig. 3B; lanes 2-4). Rubratoxin B-induced apoptosis is accompanied by DNA ladder, therefore, rubratoxin B-induced apoptosis is considered not to require protein synthesis.

The $\mathrm{Ca}^{2+}$-dependent enzymes such as protein kinase $\mathrm{C}$ often play crucial roles in apoptotic signal transduction. In fact, the $\mathrm{Ca}^{2+}$ chelator EGTA inhibited oxidized low density lipoproteininduced apoptosis ${ }^{21)}$. Accordingly, we investigated the effect of EGTA on rubratoxin B-treated 


\section{A}

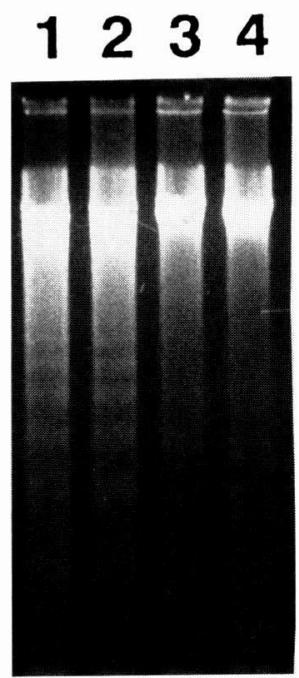

B

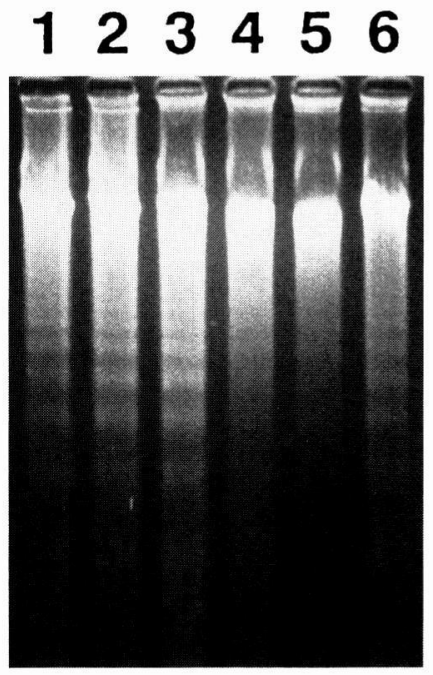

Fig. 4 Enhancement of rubratoxin B-induced DNA fragmentation in HL-60 cells by EGTA (A), and inhibition of the effect of EGTA by $\mathrm{CaCl}_{2}$ (B). (A) Lanes 1-4 correspond to HL-60 cells treated with 2, 1, 0.5 and $0 \mathrm{mM}$ EGTA in the presence of $40 \mu \mathrm{g} / \mathrm{ml}$ rubratoxin B for $8 \mathrm{hr}$, respectively. (B) Lanes 1-5 correspond to HL-60 cells treated with 2, 1, 0.5, 0.25 and $0 \mathrm{mM} \mathrm{CaCl}_{2}$ in the presence of both $40 \mu \mathrm{g} / \mathrm{ml}$ rubratoxin B and $1 \mathrm{mM}$ EGTA for $24 \mathrm{hr}$, respectively. Lane 6 corresponds to HL-60 cells treated With $1 \mathrm{mM}$ EGTA for $24 \mathrm{hr}$.

cells. Concomitant treatment with low concentration $(0.5 \mathrm{mM}$ and $0.25 \mathrm{mM})$ of EGTA did not affect rubratoxin B-induced DNA fragmentation (Fig. 3B ; lanes 8, 9). On the other hand, 24-hr treatment at high concentrations ( $2 \mathrm{mM}$ and $1 \mathrm{mM}$ ) of EGTA resulted in no DNA ladder in $40 \mu \mathrm{g} /$ $\mathrm{ml}$ rubratoxin B-treated HL-60 cells (Fig. 3B ; lanes 6, 7). Two opposing explanations for this phenomenon are considered to be possible. One is that EGTA inhibits rubratoxin B-induced apoptosis, like the case of oxidated low density lipoprotein-induced apoptosis ${ }^{21}$. Another possibility is that the effects of rubratoxin B and EGTA on HL-60 cells are synergistic. This explanation is based on the results that EGTA induced apoptosis in HL-60 cells (Fig. 4B ; lane 6), and pheochromocytoma PC12 cells ${ }^{22}$. These results suggest that EGTA is also an apoptosis inducer. To determine whether EGTA inhibits or enhances rubratoxin B-induced apoptosis, we incubated HL-60 cells with EGTA and $40 \mu \mathrm{g} / \mathrm{ml}$ rubratoxin B concomitantly for $8 \mathrm{hr}$ (Fig. 4A). Eight-hr treatment of both rubratoxin $\mathrm{B}$ and high concentrations ( $2 \mathrm{mM}$ and $1 \mathrm{mM}$ ) of EGTA induced DNA fragmentation (Fig. 4A ; lanes 1, 2), suggesting that long exposure to both chemicals led to DNA degradation after apoptosis. Consequently, the effects of both chemicals appear to be synergistic, and no DNA ladder in lanes of rubratoxin B with high concentrations ( $2 \mathrm{mM}$ and $1 \mathrm{mM}$ ) of EGTA (Fig. 3B; lanes 6,7 ) are considered to be due to post-apoptotic DNA degradation.

To determine whether EGTA itself or the reduction of extracellular $\mathrm{Ca}^{2+}$ concentration as 
a consequence of the chelating action of EGTA enhances rubratoxin B-induced apoptosis, we incubated HL-60 cells with $\mathrm{CaCl}_{2}, 40 \mu \mathrm{g} / \mathrm{ml}$ rubratoxin B and $1 \mathrm{mM}$ EGTA concomitantly for 24 hr (Fig. 4B). DNA ladders were observed when the cells were treated with high concentrations ( $2 \mathrm{mM}, 1 \mathrm{mM}$ and $0.5 \mathrm{mM}$ ) of $\mathrm{CaCl}_{2}$ (Fig. $4 \mathrm{~B}$; lanes 1-3). In contrast, addition of $0.25 \mathrm{mM}$ of $\mathrm{CaCl}_{2}$ could not inhibit post-apoptotic DNA degradation (Fig. $4 \mathrm{~B}$; lane 4). Even in the presence of $1 \mathrm{mM}$ EGTA, post-apoptotic degradation was inhibited (Fig. 4B ; lanes 1-3). Hence, EGTA itself did not appear to enhance rubratoxin B-induced apoptosis, while the reduction of extracellular $\mathrm{Ca}^{2+}$ concentration did.

In this report, we show that rubratoxin B induces apoptosis in HL-60 cells in the presence of internucleosomal fragmentation. Also, we suggest that rubratoxin B induces apoptosis without protein synthesis irrespective of the concentration of extracellular $\mathrm{Ca}^{2+}$. However, further studies are needed to elucidate the detailed molecular mechanism of toxicity.

Acknowledgement We wish to thank Dr. Mark Y. Fukayama for his editorial efforts on this manuscript.

\section{References}

1) Brnside, J. E., Sippel, W. L., Forgas, J., Caroll, W. J., Atwood, M. B., Doll, E. R. : Amer. J. Vet. Res., 18, 817 (1957).

2) Natori, S., Sakaki, S., Kurata, H., Udagawa, S., Ichinoe, M., Saito, M., Umeda, M., Ohtsubo, K. : Appl. Mycrobiol., 19, 613 (1970).

3) Hood, R. D., Innes, J. E., Hayes, A. W. : Bull. Environ. Contam. Toxicol., 10, 200 (1973).

4) Koshakji, R. P., Wilson, B. J., Harbison, R. D. : Res. Commun. Chem. Pathol. Pharmacol., 5, 584 (1973).

5) Wilson, B. J., Harbison, R. D. : J. Amer. Vet. Med. Assoc., 163, 1274 (1973).

6) Phillips, T. D., Hayes, A. W., Ho, I. K., Desaiah, D. : J. Biol. Chem., 253, 3487 (1978).

7) Hayes, A. W., Hoskins, B., Pfaffman, M. A., Watson, S. A.: Toxicol. Lett., 1, 241 (1978).

8) Siraj, M. Y., Hayes, A. W. : Toxicol. Appl. Pharmacol., 48, 351 (1979).

9) Engelhardt, J. A., Carlton, W. W., Carlson, G. P., Hayes, A. W.: Toxicol. Appl. Pharmacol., 96, 85 (1988).

10) Nagashima, H., Nishida, M., Ishizaki, Y., Morita, I., Murota, S., Goto, T.: "Animal Cell Technology: Basic \& Applied Aspcts, Vol. 8," p. 571 (1997), Kluwer Academic Publishers, Dordrecht.

11) Nagashima, H.: Mycotoxins, No. 42, 57 (1996).

12) Umeda, M., Saito, A., Saito, M.: Jpn. J. Exp. Med., 40, 409 (1970).

13) Engelhardt, J. A., Carlton, W. W., Hinsman, E. J., Hayes, A. W.: Exp. Mol. Pathol., 50, 193 (1989).

14) Cohen, J. J.: Immunol. Today 14, 126 (1993).

15) Jacobson, M. D., Burne, J. F., Raff, M. C.: EMBO J., 13, 11899 (1994).

16) Collins, R. J., Harmon, B. V., Gobe, G. C., Kerr, J. F. R: Int. J. Radiat. Biol., 61, 451 (1992).

17) Ueno, Y., Umemori, K., Niimi, E., Tanuma, S., Nagata, S., Sugamata, M., Ihara, T., Sekijima, M., Kawai, K., Ueno, I., Tashiro, F.: Nat. Toxins., 3, 129 (1995).

18) Wogan, G.N., Edwards, G. S., Newberne, P. M. : Toxicol. Appl. Pharmacol., 19, 712 (1971).

19) Engelhardt, J. A., Carlton, W. W., Rebar, A. H., Hayes, A. W.: Food. Chem. Toxicol., 26, 459 (1988).

20) Sharma, R. P.: J. Dairy. Sci., 76, 892 (1993).

21) Escargueil-Blanc, I., Salvayre, R., Negre-Salvayre A : FASEB J., 8, 1075 (1994).

22) Lindenboim, L., Haviv, R., Steim, R. : J. Neurochem., 64, 1054 (1995). 